\title{
Characteristics of development of Tajik jewelry art at the turn of the 21 st century
}

\author{
Zarrina Umarova* \\ Faculty of the History and International Relations, Russian-Tajik (Slavonic) University, 30 M.Tursunzoda Str., Dushanbe, 734025, \\ Tajikistan
}

\begin{abstract}
The paper identifies and analyzes the characteristic features of the development of Tajik jewelry art in the late 20th - early 21 st centuries. The author believes that at this time, after a long period of oblivion, there is a marked way to restoration of many lost and nearly forgotten folk traditions in Tajik jewelry art. This period of time can be distinguished as a transitional period in the history of Tajik jewelry art development. This issue carries a significant value in the history of Tajikistan because the jewelry art in the period from the 80ies of the 20th century to the early 20th century was previously not subjected to a dedicated study, which results in certain gaps in the research of modern Tajik jewelry art. Studying the characteristics of the development of jewelry art at the turn of the 21st century and of the problems faced by master jewelers (zargars) at that time will aid in the future to identify the most efficient ways of developing this industry and facilitate its becoming one of the export-oriented areas, taking into account that the Republic of Tajikistan possesses all the necessary natural resources.
\end{abstract}

\section{Introduction}

In linguistics, analysis of value preferences offers the opportunities to study the national linguistic consciousness and build a model of a linguistic persona. A language establishes and reflects the system of values, attitude, and assessment of a particular society. All of this taken together can be called a value-based worldview.

Value-based worldview is one of the aspects of the worldview and is determined as a characteristic of a system of ideals that give a person a reference point in one's preferences, goals, motives, and actions. Dominating values determine what is the most important and significant in the life of each individual. On the level of social groups of people, there exist certain accepted values that are approved by the surrounding people and unacceptable values that do not receive approval when adhered to. However, axiological dominants in culture as well as the worldview change with time. What was valued in the previous century may not be relevant today. This can be explained by the fact that socioeconomic and political changes in society can immediately change the primary hierarchy of values in the axiological system or introduce completely new values that meet the needs of the contemporary individual.

A value-based worldview contains the most culturally significant meanings and value dominants, whose combination forms a particular type of culture that is maintained and preserved in a language. Aside from that, within the framework of one language culture, this concept represents an inhomogeneous structure because different social groups can have different values. At the same time, a value-based worldview exists both in the collective consciousness and the individual one.

\subsection{Importance of the Problem}

Language, being the most surprising and complex manifestation of human nature, offers humans its tools to produce a wide variety of assessments of objects and phenomena of reality. It is language that creates, stores, and transmits the values that form the characteristic axiological domain in the linguistic culture of a particular people. It is important to study the axiological foundation of the national linguistic consciousness, build a model of the system of values, and identify the national characteristics in the axiological domain of Tajik youth.

A linguo-axiological study of value dominants of young people aged 16-25 would allow to identify the ambitions, interests, wishes, and goals of the modern young generation. Young people are the very part of the society that is the most expected to produce initiatives, development, improvements, and changes in the society.

\subsection{Purpose of the Study}

The purpose of this study is to analyze the social value orientations of the young people of Tajikistan. Studies of various aspects of associative consciousness were initiated in Tajikistan by a group of scientists of RTSU under the direction of one of the authors of this paper within the framework named "Cognitive and ethno-

Corresponding author: umarova-zarina@ mail.ru, 
psycholinguistic study of the problems of tolerance and interethnic communications" 2015-2016. In the course of the research, we studied the issues related to ethnic stereotypes, sources of intolerance in society, and national identity [1]. This research continued and lead us to understand that these aspects are closely related to the issues of language discrimination [2]. However, it turned out that the issues related to the aforementioned aspects are also closely connected with the value-based worldview. The results of the completed research made it necessary to identify the value orientation of the young people of Tajikistan and the values that form the foundation of the worldview of your youth.

\subsection{Methodological Framework}

The methodological framework of this research was formed by the axiological concepts and theories developed in the works of N.D. Arutiunova [3], E.M. Volf [4], A.N. Baranov [5], G.F. Gibatov [6], G.Ia.Golovnykh [7], A.A. Ivin [8], V.I. Karasik [9,10], D.A. Leontiev [11], N. Zerkina, and the fundamental provisions expounded by Samuel L.Hart [13] and others [14].

The main methods of this research are free association experiment, descriptive method, and the method of analysis and synthesis.

The free association experiment is an efficient method for identifying verbal associations that can yield information about the deep structures of the language consciousness. The nature of the free association experiment consists in the following: informants answer stimulus words $(\mathrm{S})$ with reaction words $(\mathrm{R})$ that come to their minds first and the experimenter does not constrain the subjects with either formal or semantic features of reaction words.

The empirical data obtained in the course of the experiment were classified and divided into the following groups: paradigmatic responses, syntagmatic responses, phrase responses, sentence responses, cliché responses (set phrases, sentences), and proverb responses. In syntagmatic responses, their grammatical class does not match with the stimulus word, and such associations are always in predicative relations. For example, $\mathrm{S}$ education $-\mathrm{R}$ higher, $\mathrm{S}$ career $-\mathrm{R}$ important. Associations are paradigmatic when the reaction words belong to the same grammatical class as the stimulus words. For example, S education - R intellect, S career R money.

The next stage of the research of value dominants was the analysis of reactions to identify special characteristics of the common human and modern values of young people. Also, an attempt was made to identify reactions to stimulus words that bear (positive or negative) evaluative character if such were available in the informants' answers. The outcome of value analysis was concluded by estimating the number of reactions given to the stimulus word and identifying the share of unique and non-unique answers.

In the course of the associative experiment, the respondents were offered the total of 16 values, 8 of which are common human (basic) values such as family, health, friends, love, faith (religion), honesty, respect for elders, and kindness. The other 8 values pertain to the modern society: career, money, wealth, physical attractiveness, education, tolerance, independence, and success.

During the associative experiment, the respondents had the goal to write the first associations with the presented stimulus values that came to their minds. 10 minutes were given to complete this task and the participants were also given the opportunity to offer several associations for one stimulus.

This paper considers only some of the associations with our young people's modern values.

\section{Results and Discussion. Modern values of Tajik young people}

\subsection{Education value}

In the past several years, education attained a completely different value and notion in the understanding of contemporary young people as compared to the education in the Soviet period. Education has become an inseparable part of the making of a modern "sustained" person in the period of the unstable way of life of the modern society and the world in general. The demand from the society for qualified specialists requires a modern person to possess a certain set of knowledge, skills, and abilities necessary in people's professional and business activities. In the current unstable society, an educated person manages to adapt to social and political changes in the life of the society easier and quicker. A person's living standards also started to be immediately dependent on one's education. There is no surprise that, realizing these factors, the younger generation seeks to get an education to ensure their own stability and confidence in the future.

During the study of the "education" value, it was identified that young people highlight the high significance and indispensability of getting an education with the reactions: important 4, most important 2 , need, most necessary 2, everyone must have 3, obligatory 2, demanded, and obligation. First of all, a person strives to get an education to develop oneself and become an intelligent person (to develop the individual, erudition, intelligence, mind, strengthening for brain development). According to the definition given by the subjects, education is characterized as higher 19, secondary, normal, good, and excellent. It is not surprising that students gave the reaction higher to the "education" stimulus because at the current stage of their lives they work to get a higher education. There also were reactions, whose appearance was conditioned by the process of education: study 4, knowledge 2, RTSU 2, university 2, docent, school, and reading. Young people associate education with further successes and getting a degree (have a diploma), and also associate it with a person's pride and glory. One informant expressed one's concern with the low quality of education in the city.

The analysis of the results identified that the "education" stimulus word produces the following paradigmatic responses: study, mind, work, knowledge, $R T S U$, university, career, human, docent, obligation, 
erudition, pride, self-improvement, glory, reading, intelligence, school, future; syntagmatic responses: higher, important, need, needed, necessarily, secondary, normal, demanded, good, excellent; phrase responses: most important, most needed, successful career, to develop the individual, mental development, further success, have a diploma, without oppressive teachers; sentence responses: everyone must have; low quality of education in the city; strengthening for brain development.

The associative field of the "education" stimulus word in terms of reaction frequency is represented by the non-unique responses: higher 19, (most important 2) important 6, (most needed 2, need 1) necessary 5, study 4 , mind 6, everyone must have 3, work 3, knowldge 2, RTSU 2, university 2, (successful) career 2, necessarily 2; and the unique responses: secondary, human, docent, normal, to develop the individual, obligation, erudition, low quality of education in the city, pride, selfimprovement, glory, mental development, reading, intelligence, school, further success, have a diploma, future, strengthening for brain development, demanded, good, excellent, without oppressive teachers.

The total number of responses was 177 , the share of unique responses was $23(13 \%)$, the share of non-unique responses was $154(87 \%)$.

\subsection{Wealth value}

A person gets actively involved in the process of creating, accumulating, and storing wealth. Wealth has a significantly important and valuable meaning in the mind of the people. However, the definition of wealth is ambiguous because every person determined by wealth personally determines what wealth is and what place does this person place it in one's axiological system of worldview. Regardless of the individual character of the definition of the "wealth" value, a person lives one's life in society, which involuntarily influences all of its members, "forcing" them to adhere to a certain uniformity in opinion, thus ensuring the integration of society. Because of that, the interaction between people in the same environment produces a relative commonly recognized concept of the value and significance of wealth in the lives of individuals. By determining what wealth is, what significance is ascribed to it, and which way it can be achieved in a particular people's linguistic culture, it is possible to make an important conclusion about what kind of target does a people set for its future development.

In the course of analysis of students' responses to the "wealth" stimulus, it was identified that young people associate wealth with both material and non-material benefits. The non-material benefits are such common human values as family 13, happiness 8 , health 7 , loved ones 2 (when the loved ones are near), parents, love, respect, friends, relatives, mother, and child. The material benefits are money 12 , resources, property, necessary things, luxury, and home, that can be deserved and earned by working (work several years, earn). For a person, it is better to have moderate wealth that brings peace in the house. According to the respondents, wealth is an achievement, renown, and career of a person and also is a source of prosperity, success, and power. The respondents believe that it is not always possible to be rich (it is transient), that wealth does not depend on money and is not important in a person's life (not that important, nothing) and sometimes brings its owner evil and enemies. At the same time, wealth grants a person the feeling of satisfaction and full life (I made it in life).

This way, the respondents' answers contained the following paradigmatic responses: family, money, happiness, health, labor, book, loved ones, parents, love, prosperity, respect, resources, friends, success, necessity, enemies, relatives, mother, property, house, luxury, achievement, child, career, evil, renown; syntagmatic responses: work, earn, unimportant, moderate, oh yes!, needed, it's alright; phrase responses: work several years, can be earned, not that important, will be rich, have it all, necessary things, does not depend on money, I made it in life, peace in the house, it is transient; sentence responses: when you have a good girlfriend; when the loved ones are near; you can't always be rich; it's a pity that people think so much of wealth.

The associative field of the "wealth" stimulus word in terms of reaction frequency is represented by the nonunique responses: family 13 , money 12 , happiness 8 , health 7, (labor 1, several years 1) work 3, (earn) can be earned 2, book 2, when you have a good girlfriend 2, (when the loved ones are near) loved ones 2, parents 2, love 2, prosperity, respect 2, (not that important) unimportant 2; and unique responses: will be rich, have it all, necessary things, does not depend on money, it is not always possible to be rich, resources, friends, moderate, oh yes!, success, necessity, it's a pity that people think so much of wealth, enemies, relatives, need, mother, property, nothing, house, luxury, I made it in life, power, peace in the house, achievement, child, career, evil, it is transient, renown.

The total number of responses was 91 , the share of unique responses was $30(33 \%)$, the share of non-unique responses was $61(67 \%)$.

\subsection{Career value}

In the modern society, a human, aside from the personal relationships with the members of one's own society, has social and business connections with other members of this society. This means that a person is actively engaged in a professional area of activity that offers opportunities to apply one's exceptional skills, abilities, and knowledge in practice. But work offers not only a professional medium to apply and develop a person's professional qualities but also provides an incentive and motivation to advance along the so-called "career ladder". Career became a completely new and relevant value in the modern age, in the 21 st century. Young, educated, and ambitious people spend more time, energy, and efforts to reach high position in society. A successful career is one of the manifestations of the image of such position.

The question of whether career is valuable for today's Tajik youth can be answered by human language consciousness. The lexemes that a person uses in one's 
language consciousness can describe this person's characterization, assessment, or vision of the phenomena of the environment. This way, a free association experiment identified that the subjects of this research, RTSU students from various majors, understand career as a means of achieving material and non-material benefits. They consider that material benefits include money 11, own business 4, company, wealth and material well-being. Career also brings a person immaterial benefits in the form of success 4 , respect 3 , achievement, experience, self-fulfillment, way to selfdevelopment, and status. In the understanding of young people, a career must be successful and spectacular 2 but such career is achieved only through a person's effort 4 , commitment, and hard work. Career is also related to a person's professional activity (favorite profession, lawyer 2, management, manager, bank director). For some respondents, a career is the goal of their life (go toward your goal, what we aspire to) and is connected with hopes for the future (in the future, will be insha'Allah, not yet but later). Young people believe making a career to mean growth through the years, be better than everyone and achieve the best. In addition, when making a career, a person gets the opportunity to use knowledge in the career and help people.

The opinions of the informants about the significance of career are mixed. The highest significance of the value of career is given in the reactions of need, necessary, most important, in the first place. Lower significance can be seen in the responses kind of important 2, nonsense, not the most important in life.

The analysis of the results identified the following paradigmatic responses: money, business, goal, hard work, labor, success, successful, respect, lawyer, achievement, work, experience, management, manager's, development, girlfriend, self-fulfillment, independence, nonsense, dream, company, status, wealth, profit; syntagmatic responses: in the future, need, necessary, spectacular, successful, make, think; phrase responses: own business, will be insha'Allah, kind of important, be better than everyone, most important, bank director, way to self-development, growth through the years, favorite profession, material well-being, help people, on the most important in life, achieve the best, go toward your goal, in the first place; sentence responses: not yet but later; all efforts and work of a person; use knowledge in career; what we aspire to.

The associative field of the "career" value in terms of reaction frequency is represented by non-unique and unique responses. Non-unique responses: money 11 , (own 1) business 4, goal 4, (hard work 1) labor 4, (successful 1) success 4, respect 3, will be insha'Allah 2, kind of important 2, in the future 2, (need) necessary 2, lawyer 2, achievement 2, spectacular 2, work 2. Unique responses: successful, experience, be better than everyone, management, manager's, not yet but later, make, development, all efforts and work of a person, use knowledge in career, girlfriend, self-fulfillment, most important, think, independence, bank director, nonsense, way to self-development, dream, growth through the years, favorite profession, company, status, wealth, material well-being, help people, profit, not the most important in life, achieve the best, go toward your goal, in the first place, what we strive to.

The total number of responses was 80 , where the share of unique responses was $34(43 \%)$ and the share of non-unique responses was $46(57 \%)$.

\subsection{Success value}

One of the main values of a contemporary person is success. The notion of success is hard to determine unambiguously. The ambiguity is conditioned by the fact that the nature of a person's success, consisting of particular separate small successes in different areas of human activity, is understood differently by different people. This again depends on a person's hierarchy of values, on what a person's primary orientation in life is. For example, if an individual wants to get a high-paying job, one will study well and make efforts to get a prestigious degree in a high-profile university, which will indicate the interest in a high-quality education. Otherwise, a person wants to have a solid family, raise well-educated and cultured children, so all of this person's time, resources, efforts, and thoughts will be aimed at attaining family happiness. In these cases, a person who gets a high-paying job or has a good family will be right to consider oneself a successful person. The examples above illustrate the subjective perception of success by people. However, modern society has determined a general set of criteria for a person's success. This set of success criteria was identified in the reactions of the subjects in the course of a free association experiment.

This way, modern Tajik young people associate success with success in career 6 , influence on society 2 , money 2, position, social status, wealth, business, work, and profession (being a good specialist in one's profession). This series of associations can be called the components of social success. But the reactions of family 2, happiness, mother, and home indicate that success is also achieved by a person in personal life. Most of the informants hare the opinion that a person becomes successful through making effort (achieve success, study and work a lot, set the goal and achieve it), hard work (work hard 2, aspiration, result of hard work), labor (labor 2, hard work, years of working), self-development (experience, good intellect, smart mind, since childhood) and personal traits (confidence 2, skill, proactivity, wit). Also, success is sometimes a result of luck and chance. Young people highlight the importance of being successful in the following reactions: need 2, necessarily, yes, best in life, and naturally. In general, it can be concluded that the attitude of modern young people toward success can be characterized as a goal that brings material and "spiritual" benefit and must be achieved in the future.

The analysis of the results identified that the "success" stimulus word produces the following paradigmatic responses: career, in career, hard work, labor, confidence, family, money, influence, wish, aspiration, position, in life, in business, mother, wealth, happiness, since childhood, skill, strategy, luck, chance, wit, experience, home, work, profit, goal, proactivity; syntagmatic responses: no, need, work hard, will come, 
in everything, necessarily, yes, naturally, mediocre, personal; phrase responses: self-confidence, family success, influence in society, years of work, study and work a lot, result of hard work, best in life, status in society, achieve success, set a goal and achieve it, good intellect, smart mind; sentence responses: it is not always possible to be successful; being a good specialist in one's profession; I don't have success yet.

The associative field of the "success" stimulus word in terms of reaction frequency is represented by the nonunique responses: (in career 1) career 6, (hard work 1) labor 3, no 2, need 2, (self-1) confidence 2, work hard 2, (family success) family 2, (in society) influence 2, money 2; and unique responses: years of work, wish, aspiration, will come, position, study and work a lot, in life, in everything, necessarily, yes, result of hard work, it is not always possible to be successful, best in life, in business, naturally, mother, wealth, happiness, being a good specialist in one's profession, I don't have success yet, mediocre, status in society, since childhood, skill, strategy, achieve success, luck, set a goal and achieve it, chance, wit, experience, personal, good intellect, home, work, profit, goal, proactivity, smart mind.

The total number of responses to the "success" stimulus was 62, the share of unique responses was 39 $(63 \%)$, the share of non-unique responses was $23(37 \%)$.

\section{Conclusion}

As a result of the analysis of modern values in the system of the axiological area of young people, the largest numbers of reactions were obtained for the values of education 177, wealth 91, and career 80. A larger number of reactions ensured a high percentage of nonunique responses, which means a high uniformity of young people's concepts of education, wealth, and career.

Modern young people highly appreciate education in their lives and make efforts to get it. The study identified the particular importance of getting a higher education, which develops a person's intellectual capabilities and is a key to a successful career and material well-being. Young people further depart from the previously common idea of getting a higher education only for the sake of getting a formal degree. They want to gain solid high-quality knowledge. This is what the modern trend in the labor market requires: highly qualified and competent employees, making this a required element of competitiveness in any area of business.

In the respondents' language consciousness, the value of wealth is first of all associated with such common human values as family, health, parents, happiness, love, and respect, which indicates a high level of young people's orientation at creating and obtaining higher values of human life that do not depend on money.

The modern youth that aspires to get an education wants to achieve success and make a successful career in the future. In young people's understanding, a career is a means of achieving high social positions (respect, influence, status, image, material well-being, etc.), which are represented by material and non-material benefits. At the same time, young people understand that in our days a successful career is only made by work, knowledge, and effort by the person oneself.

Young people associate success with achieving career success, money, social influence, and status. A person gains success through self-development, skill, wit, and proactivity, which means putting work and effort to achieve success in any area of human life.

This way, after analyzing the modern values of young people of Tajikistan, we come to the conclusion that young people are socially active, focused in their aspirations, and want to achieve success, influence, and status in society by means of getting an education, achieving material well-being, and making a career.

The obtained results allow to understand the value orientations of the modern youth better and introduce measures to regulate and solve possible problems of moral education, it being critical for the well-being of society and for the future of the country in general.

\section{Acknowledgements}

The authors express their gratitude to the Russian-Tajik (Slavonic) University for financing the research under the University Development Program for 2018.

\section{References}

1. S.A. Iatsenko, Dress of the peoples of Eurasia (Iranian language peoples), 664 p. (Moscow, 2006)

2. L.A. Chvyr, Tajik jewelry (Moscow, 1977)

3. O.A. Sukhareva, History of Central Asian dress: Samarkand (second half of the 19-20th centuries) ( Moscow, 1982).

4. O.A. Sukhareva, Late feudal city of Bukhara in the late 19th - early 20th centuries: crafts industry. (Tashkent, 1962)

5. E.S. Ermakova, Bukhara jewelry in the late 19th early 20th centuries (the problem of ethnocultural connections), (Moscow,1994)

6. Z.A.Shirokova, Tajik dress of the late 19th - early 20th cc. (Dushanbe, 1993)

7. G.M. Maitdinova, History of Tajik dress, (Dushanbe, 2004)

8. D.A. Fakhretdinova, Art of jewelry in Uzbekistan, (Tashkent, 1988)

9. Z.Kh. Umarova, History of development of Tajik jewelry art (5th-early 20th cc.), (Dushanbe, 2017)

10. I.Iu. Perfileva, Russian jewelry are of the second half of the 20th century: Main artistic trends and directions, (Moscow, 2000)

11. Materials of the State Tajik Archive. F.No.1794, list No.3, case No.92, 93, 95

12. E.Neva, Tajik jewelry, 24 (Boston, 2010)

13.B.A. Rybakov, Cosmogony and mythology of farmers of the Chalcolithic, (SA. No.1, Moscow, 1965). 